\title{
World Government and the Constitution of the United States
}

\author{
William Tucker Dean, $J r . *$
}

\begin{abstract}
A ITHOUGH plans and proposals for world government are by no means new, they have burgeoned since the end of the "hot" stage of World War II. Literature, largely polemical, advancing given proposals or denouncing them, has not been wanting, ${ }^{2}$ and it is not here intended to swell this flood. Rather it is proposed to consider those measures which have materialized out of the broader controversy into specific resolutions now pending in Congress. These resolutions, however general and even vague they may be, in a polity organized under a written constitution raise constitutional problems which it may be useful to examine.

The host of resolutions pertaining to world government which are now pending in the 81 st Congress may be divided conveniently into two groups, those which do not envisage, except perhaps well in the future, changes in the Constitution of the United States and those resolutions which either explicitly or inplicitly require the amendment of the Constitution to effectuate their aims. Sponsors of some of the resolutions in the latter group might contest the classification since in most of the pending resolutions no reference is made at all to constitutional amendment, but an effort will be made to show the constitutional issues involved, issues which, if not calling for amendments for their solution, imply the substitution of an entirely new constitution. It is, of course, inherent in a Congressional resolution that it be general rather than, statute-wise, specific and detailed; legal discussion of such resolutions must necessarily share the general if
\end{abstract}

* Assistant Professor of Law at New York University School of Law.

1 See, for example, the resolution adopted by the General Court of Massachusetts in 1838, quoted in 1 CoMmon CAUSE 60 (1947):

... Resolved, That the institution of a Congress of nations for the purpose of framing a code of international law, and establishing a high court of arbitration for the settlement of controversies between nations, is a scheme worthy of the careful attention and consideration of all enligbtened governinents.

2 A large proportion of the 124 items listed in Ishida, World Government Bibliography, 3 COMMMON CAUSE 212 (1949), covering books and articles relating to the problem of world government published in 1948 and 1949, are either pleas for or attacks on some variety of world government. 
not vague character of the propositions under study, but this may not be without value if it points up both opportunities and perils that lie at the next stage of more precise legislative formulation.

RESOLUTIONS WHICH DO NOT ENVISAGE CHANGES

IN THE CONSTITUTION

The Resolution of the American Association for the United Nations

As might be expected in the light of the archaic organization and muddle-headedness that characterizes the Congress of the United States, ${ }^{3}$ many of the world government resolutions have originated not from Congressional wisdom but from the pressure groups, driven to needling Congress into action both by the existence of competing pressure groups and the massive inertia of Congress itself. One of the more distinguished and public-spirited of such groups is the American Association for the United Nations, ${ }^{4}$ primarily devoted to public education but pressed into legislative activity because of the implications of some world governnent proposals for the United Nations the Association seeks to uphold. Under the inspiration of the Ainerican Association for the United Nations, Senate Concurrent Resolution $72^{5}$ has been introduced. A comprehensive and moderate program to improve the United Nations within the Charter, the Association Resolution does go so far as to add "or ultimately, if necessary, by amendment of the Charter." ${ }^{\circ}$ It is with specific proposals for improvement within the framework of the Charter that the resolution is primarily concerned, however. Briefly, these call for voluntary agreement to limit the veto in the Security Council, ${ }^{7}$ elimination of the reservations made by the United States in its acceptance of the Statute of the International Court of Justice, development of an armed guard to protect United Nations missions in the field, renewed political negotiations for armed forces under Article 43 of the Charter, utilization of Article 51 of the Charter for measures of collective self-defense, ${ }^{8}$ administration of disputed areas by the United Nations, provision of revenue sources for the United Nations in addition to the national

3 Burns, Congress on Triad: THe Politics of Modern Law-Making (1949) competently marshals the evidence and points, unheeded, a way out.

4 A summary of the objectives of the AAUN as well as of other groups in the world government field will be found in HART, TOWARD CoNSENSUS FOR WORID LAW AND ORDER (1949).

E Appendix A, infra at p. 469.

6 Ibid.

7 See SEN. Res. 239, 80th Cong., 2d Sess. (1948) to the same effect.

8 Kelsen, Collective Security and Collective Self-Defense under the Charter of the United Nations, 42 Axr. J. INT'工 L. 783 (1948). 
contributions, support for the fundamental freedoms enunciated in the Charter, preparation of an international criminal code and a statute for an international criminal court, ${ }^{8}$ and, finally, operation of the American program of technical assistance to underdeveloped areas ${ }^{10}$ through the United Nations.

A number of these recommendations have constitutional implications. Those involved in the reservations made by the United States to its acceptance of the optional clause of the Statute of the International Court of Justice have been explored elsewhere ${ }^{11}$ as have the implications of Article 43 of the Charter and the war power in the Constitution. ${ }^{12}$ The legal impact of the fundamental freedoms of the Charter on American law has recently begun to receive some judicial recognition in the United States with respect to interracial inarriages ${ }^{13}$ and restrictions on land ownership by aliens. ${ }^{14}$ Two of the recommendations carry the promise of ultimate though not immediate constitutional change: provision of independent sources of revenue for the United Nations might require yielding some measure of the taxing power of the Constitution, ${ }^{15}$ although in so small a measure as to create no serious problem. The 1949 budget of the United Nations was $\$ 3,000,000$ less than that of the New York City Department of Sanitation ${ }^{16}$ and the share of the United States at least could be increased considerably without serious difficulty. One possible device, for example, would be to empower the United Nations to collect a small tax on international transportation and international mails and telegraphs.

9 Pella, Towards an International Criminal Court, 44 Ax. J. INT'L L. 37 (1950).

10 President Truman's Inaugural Address, SEN. Doc. No. 5, 81st Cong., 1st Sess. (1949).

11 Hudson, The World Court: Anerica's Declaration Accepting Jurisdiction, 32 A. B. A.J. 832 (1946); Wilcox, The United States Accepts Compulsory Jurisdiction, 40 AM. J. INT'L L. 699 (1946) ; Preuss, The International Court of Justice, the Senate, and Matters of Domestic Jurisdiction, 40 AM. J. INT'L L. 720 (1946).

12 U.S. Const. Art. I, \& 8. Borchard, The Charter and the Constitution, 39 Ar. J. INT'L L. 767 (1945); Strauss, Constitutionality of Participation in a Council to Police the Peace, 18 Tenn. L. Rev. 646 (1945).

13 Concurring opinion of Mr. Justice Carter in Perez v. Lippold, 32 Cal. 2d 711, 732, 198 P. 2d 17, 29 (1948).

14 Sei Fujii v. California, 97 A. C. A. 154 (Apr. 24, 1950). See N.Y. Times, Apr. 26, 1950, p. 16, col. 3 discussing the Fujii case and the invalidation in 1947 of an antiSemitic lousing ordinance by an Ottawa, Canada magistrate's court. $C f$. the concurring opinion of Mr. Justice Black in Oyama v. California, 332 U.S. 633 (1948). Contra: Sipes v. McGliee, 316 Mich. 614, 25 N. W. 2d 638 (1947); Kemp v. Rubin, 69 N. Y.S. 2d 680 (Sup. Ct., Spec. Term, Queens Co. 1947).

15 U.S. CoNST., Art. I, \& 8.

${ }^{16} \mathrm{HART}$, op. cit. supre note 4, at 9. 
More significant are the implications of an international criminal court over which controversy is raging already. ${ }^{17}$ In view of the promulgation of the Nürnberg Charter, ${ }^{18}$ however, as well as the long established international law of extradition, it does not appear that a carefully drawn code of international criminal law and a statute for an international criminal court need go farther beyond the Fifth and Sixth Amendments than the treaty-power ${ }^{19}$ can reasonably extend. ${ }^{20}$

\section{Thomas-Douglas Resolution}

A single feature of the Resolution of the American Association for the United Nations, ${ }^{21}$ utilization of Article 51 of the Charter, is the core of the Thomas-Douglas proposal, Senate Concurrent Resolution $52,{ }^{22}$ introduced by Senators Thomas and Douglas. Article 51 of the United Nations Charter provides:

Nothing in the present Charter shall impair the inherent right of imdividual or collective self-defense if an armed attack occurs against a Member of the Umited Nations, until the Security Council has taken the measures necessary to maintain international peace and security. Measures taken by Members in the exercise of this right of self defense shall be immediately reported to the Security Council and shall not in any way affect the authority and responsibility of the Security Council under the present Charter to take at any time such action as it deems necessary in order to maintain or restore international peace and security.

Premising the constitutionality of the Umited States ratification of the United Nations Charter, the Thomas-Douglas Resolution calls for an agreement under Article 51, open to all Members of the United Nations, that if the Security Council fails to come to the aid of a victim of attack other machinery of the United Nations is to be employed.

17 The problem in relation to pending international measures is considered by Pella, supra note 9; Liang, Notes on Legal Questions Concerning the United Nations, 43 Aw. J. INT'L L. 460, 479 (1949); Ely, International Courts of Appeal: A Judicial Approach to World Order, 35 A. B. A. J. 105 (1949); Rix, Human Rights and International Lav: Effect of the Covenant Under Our Constitution, 35 A. B.A. J. 551 (1949); Carlston, The Genocide Convention: A Problem for the American Lawyer, 36 A.B.A. J. 205 (1950).

1839 Axr. J. InT'2 L., Supp. 258 (1945).

10 U. S. CoNst., Art. II, \& 1 .

20 Useful recent explorations of the treaty-power include CowLEs, TrEatres aND Consmrutronat Law (1941); Levitan, The Foreign Relations Power: An Analysis of Mr. Justice Sutherland's Theory, 55 YALE L. J. 467 (1946) ; Magnusson, Our Membership in the United Nations and the Federal Treaty Power under the Constitution, 34 VA. L. REV. 137 (1948).

21 Appendix A, infra at 469.

22 Appendix $\mathrm{B}$, infra at 470 . 
In that event signatories to the proposed agrèement will "take such steps as may be required to remove... [the dispute] from the agenda of the Security Council," a provision to meet the limitation of Article 12, Section 1 of the Charter that the General Assembly shall not make any recommendation with respect to a dispute while it is before the Security Council. The dispute may then come before the General Assembly and the signatories of the proposed agreement pledge themselves to come to the aid of the victim of attack if requested by a twothirds vote of the General Assembly, including three of the permanent members of the Security Council as an attenuated survival of the veto. Nothing having been accomplished to date under Articles 45-47 of the Charter, governing national armed contingents to be available to the Security Council, the proposed agreement is to specify the forces that will be furmshed to the Security Council under those Articles and, what is much more important, the forces to be furnished upon call of two-thirds of the General Assembly including three permanent members of the Security Council.

If the premise is correct that the adoption of the United Nations Charter with its requirements for furnishing American forces to the Security Council is in accord with the Constitution, as now seems to be generally accepted, then indeed furnishing American forces to the United Nations pursuant to an agreement under Article 51 of the Charter should not raise any new American constitutional issue, although there might be a United Nations constitutional difficulty in this utilization of Article $51 .^{23}$

\section{The Culbertson Resolutions}

Two resolutions pending in Congress owe their inspiration to Ely Culbertson and the Citizens Committee for United Nations Reform which has been organized to publicize Culbertson's original proposals. The first of the two to be introduced, House Concurrent Resolution $5,{ }^{24}$ was followed by Senate Resolution $133^{25}$ after the signing of the North Atlantic Treaty: ${ }^{26}$ the latter version represents an adaptation of the Culbertson approach to the situation created by the North Atlantic Treaty. House Concurrent Resolution 5 recommends revision of the United Nations Charter with the approval of all permanent

23 Heindel, Kalijarvi, Wilcox, The North Atlantic Treaty in the United States Senate, 43 AMr. J. INT'L L. 633, 637 (1949).

24 Appendix $C$, infra at 471.

25 Appendix $D$, infre at 473 .

26 U.S. Dept. of State Publication 3464, Generat Foreign Policy Sertes 8 (1949). 
members of the Security Council (i.e., U.S.S.R.), if possible, otherwise by an agreement under Article 51 "or in any manner acceptable to the majority of member states," but the resulting grouping is to remain open to states not joining initially. The respects in which the Charter is to be revised are specified in sone detail: the Security Council veto is made inapplicable to matters of aggression, armainent and admission to membership in the United Nations, and aggression is defined as an attack with weapons of violence or illegal occupation. Heavy armaments are placed under a rigid quota system, and atomic energy is to be controlled according to the original United States proposals to the United Nations. The make-up of the Security Council is to be altered, likewise the International Court of Justice. A world police force is to be recruited from among the citizens of the smaller nations whose utilization along with that of the national contingents of the great powers as reserves is designed to malke it unlikely that any nation bent on aggression can withstand the international force plus the national contingents.

It is apparent that the revisions, however wise or unwise they may be, do not raise any greater constitutional problems than would arise under the present Charter. Special consideration is given, in fact, to possible conflicts between national constitutions and the obligation of the national contingents to act as reserves for the world police force by the provision that nations furnishing these national forces shall do so "subject to their constitutional processes."

The revised Culbertson Resolution indicates more precisely that the Charter is to be revised, if possible under Articles 108 or 109, which provide respectively for amendments and for revision by General Conference, or else under Article 51 by a pact which clearly would, for all important purposes, replace the present Charter. To fit the situation created by the North Atlantic Treaty ${ }^{27}$ an emergency international force is to be created in a fashion similar to the international police force in the first Culbertson Resolution, and it is to be supported in part with the military assistance provided under the North Atlantic Treaty ${ }^{23}$ with command vested in the Defense Committee established by the same pact. ${ }^{29}$ Representation on the Defense Committee is specified, and the Committee is to act on major decisions on the affirmative vote of six of its seven members. Since United States materiel but not United States armed forces would be in the

$2 \pi$ Ibid.

28 Id., Art. 3.

29 Id., Art. 9. 
international contingent subject to the Committee's call, no new constitutional problem appears to arise under the revised Culbertson Resolution.

\section{The White Resolution}

Idaho's representatives in Congress can scarcely be accused of ignoring the problems of world government. In addition to a resolution offered by Senator Taylor of Idaho, which will be discussed below, Representative White of Idaho has submitted House Concurrent Resolution $100 .^{30}$ Starting off with wording identical with that of the World Federation Resolution shortly to be described, Mr. White's resolution suddenly goes off in another direction by calling for an International Charter to replace the United Nations Charter which, we are cautiously assured, is to "create no supergovernment and will insure the retention of sovereignty of every nation." A World Court "composed of proportionate representatives of the signatory nations," an International Commission, and an imternational army, "each signatory nation to have proportionate representation," though on what basis is not revealed, are to be established. The Commission is to maintain freedom of the air and freedom of the seas with universal disarmament and all international disputes are to be settled by the Commission "under the rules of judicial procedure with right of appeal to the World Court." The anticlimax of the White Resolution, however, is the triumphant appearance of international bimetalism including an international standard by weight and fineness of gold and silver.

The White Resolution seems to suggest a rather recent introduction of its author to the problems of world government, and it can scarcely be said to pose seriously any constitutional or other problems.

The four proposals summarized so far, the American Association for the United Nations Resolution, the Thomas-Douglas Plan, the Culbertson plans and Mr. White's Resolution, represent from the point of view of American constitutional law what might be considered part of the right wing annong world government proponents, whose recommendations would have only a limited effect on the Constitution of the United States, although very widely differing consequences for the United Nations. In another day this common quality might have assured overwhelming support to this congeries of plans but in the prevailing constitutional climate other considerations prevail, and it

${ }^{30}$ Appendix E, infra at 474. 
is among the second group of resolutions that the strongest Congressional support is centered, constitutional difficulties notwithstanding. ${ }^{31}$

\section{RESOLUTIONS ENVISAGING AMERICAN CONSTITUTIONAI CHANGES}

\section{The Atlantic Union Resolutions}

The origin of the Atlantic Union Resolution is the idea of Clarence K. Streit's, embodied in his book Union Now in 1939. Although the book has reappeared in a postwar edition, ${ }^{32}$ and an association, Federal Union, Inc., was organized to spread the idea, Streit's followers have not succeeded in placing their views before the current Congress in the form of a resolution. Instead a new group has literally burst into being under the distinguished leadership of $\mathrm{Mr}$. Justice Roberts, Judge Robert P. Patterson and former Undersecretary of State Will Clayton; their Atlantic Union Committee seized upon the North Atlantic Treaty ${ }^{33}$ as a vehicle for an international federal union. The Atlantic Union Committee has not developed its program in anything like the detail that Federal Union, Inc. has done, and Senate Concurrent Resolution 57, ${ }^{34}$ backed by the Atlantic Union Committee, is not very explicit. After a long preamble, reciting the advantages of federal government for free peoples, the resolution itself nierely urges:

That the President is requested to invite the democracies which sponsored the North Atlantic Treaty to name delegates, representing their principal political parties, to meet this year with delegates of the United States in a federal convention to explore how far their peoples, and the peoples of such other democracies as the convention may invite to send delegates, can apply among them, withm the framework of the United Nations, the principles of free federal union..$^{35}$

As between the plans of Federal Union, Inc. and the Atlantic Union Committee "the essential difference ... is that the Atlantic

31 In a compilation dated Mar. 1, 1950, released by the United World Federalists, 21 Senators were listed as sponsoring the Atlantic Union Resolution and 22 the World Federation Resolution, with duplications, as against 11 for the revised Culbertson Resolution and two each for the Thomas-Douglas and American Association for the Umited Nations Resolutions.

32 Strett, Unton Now: A Proposal for Atzantic Federal Unton of the Free (1949).

${ }^{83}$ Supra note 26.

34 Appendix F, infra at 475. Corresponding resolutions in the House of Representatives are H. RES. 107, 81st Cong., 1st Sess. (1949). Compare SeN. CoN. REs. 12, 81st Cong., Ist Sess. (1949): ". . . That Congress favors the political federation of Europe."

35 Appendix $F$, infra at 475. 
Union proposal contemplates initial sponsorship of the Federal Convention by only those democracies which sponsored the Atlantic Pact."36

The proposed international federal convention would, under the resolution, have authority to do no more than "explore" but the only limitation on the scope of the exploration is that it be "within the framework of the United Nations." The parallel to the epochal resolution of the Congress organized under the Articles of Confederation is impelling:

Whereas there is provision in the Articles of Confederation and Perpetual Union, for making alterations therein, by the assent of a Congress of the United States, and of the legislatures of the several States; and whereas experience hath evinced that there are defects in the present confederation, as a means to remedy which, several of the States, and particularly the State of New York, by express instructions to their Delegates in Congress, have suggested a convention for the purposes expressed in the following resolution; and such Convention appearmg to be the nost probable means of establishing in those States a firm national Government.

Resolved, that in the opinion of Congress, it is expedient, that on the second Wednesday in May next, a Convention of Delegates, who shall have been appointed by the several States, be held at Philadelphia, for the sole and express purpose of revising the Articles of Confederation, and report to Congress and the several Legislatures, such alterations and provisions therein, as shall, when agreed to in Congress, and confirmed by the States, render the federal Constitution adequate to the exigencies of Government, and the preservation of the Union. ${ }^{3 \pi}$

What might emerge from such an international federal convention is as impossible to predict as it would have been to foresee what was to issue from the Philadelphia Convention of 1787 , but it is scarcely to be imagined that the Constitution of the United States could be adapted to any meaningful world federal structure by no more than the traditional type of amendment. It is true that after the promulgation of the Constitution of the United States none of the Thirteen States found it necessary even to amend their respective constitutions, which continued to be useful in subordination to the national constitution. At that time, however, a federal government of limited powers was being erected over state governments in which the entire governmental authority was centered in the respective

36 HART, op. cit. supra note 4, at 18.

3r.U.S. DEfT. OF State, Documentary Hustory of the Constifution of the UNITED STATES OF AMIERTCA 1786-1870 (1894). 
state governments. What authority was lost by the states was simply transferred to the national government. The situation today, however, requires that a hierarchy of federal governments be constructed, an international one over a national one and with the governments of the American states beneath them, since it has not been seriously contended that all of the present powers of the federal government of the United States be transferred to what might be called the Atlantic federal government. ${ }^{38}$ Indeed, the Atlantic Union resolution seems to envisage the continued existence of the American state governments, a federal government of the United States above it, a federal governinent uniting the North Atlantic Treaty signatories which itself would be part of the structure of the United Nations, in turn a kind of loose international government. ${ }^{39}$

It is true that the proposed international federal convention might conceivably plan a governmental structure in which the American states and the foreign signatories of the North Atlantic Treaty might join in a single federal government, or, more simply, that the foreign signatories might simply apply for admission to the United States of America, but the former solution would seriously imperil approval of the plan in the United States where elements jealous of present American federal authority are still potent and if the latter were likely to occur it presumably would have occurred already.

The submittal of a North Atlantic federal union constitution to the United States would probably require a drastic realignment of the present distribution of powers between the state and American federal governments, but in the absence of a specific North Atlantic federal constitution it is impossible to say what the result might be. If the new federal convention were to be adopted by the United States, probably pursuant to a method laid down in the instrument itself, then in the calmer international atmosphere expected to prevail internal relationships of the states and the American federal government could somehow be adjusted and embodied in a new document.

\section{World Federation}

At the instigation of the largest ${ }^{40}$ world government group in the United States, United World Federalists, Inc., as well as a number of

${ }^{38}$ Among the few useful examinations of this problem are Tugwell, Can the United Nations Become a World Government?, 2 Comaron Cause 244 (1949) and Davenport, The Approach to World Government Through the Technique of the World Constitutional Convention: American Experience, 3 Miañ L. Q. 500 (1949).

${ }^{39}$ See Wright, et al., The U.N. Charter as a World Constitution, 2 Common Cause 220 (1949); Dean, International Legislation, 33 A. B. A. J. 878 (1947).

40 HART, op. cit. supra note 4 , at 29. 
other cooperating organizations, Senate Concurrent Resolution $56^{41}$ has been introduced as well as no less than 35 identical resolutions in the House of Representatives. ${ }^{42}$ Nothing could be simpler than the resolution itself:

Resolved by the Senate (the House of Representatives concurring), That it is the sense of the Congress that it should be a fundamental objective of the foreign policy of the United States to support and strengthen the United Nations and to seek its development into a world federation, open to all nations, with defined and limited powers adequate to preserve peace and prevent aggression through the enactment, interpretation, and enforcement of world law.

On the face of it the resolution is a mild one, constitutionally speaking, because the United States is already a Member of the United Nations pursuant to its own existing constitutional processes. It is swiftly apparent, however, that "development into a world federation" will require action under Articles 51, 108 or 109 of the Charter, since the United Nations is in no sense a world federation as presently organized and suppleinentary agreements under Article 51, amendments under Article 108 or a General Conference under Article 109 would be the possible steps toward world federation. ${ }^{43}$ The "defined and limited powers adequate to preserve peace and prevent aggression" could not be turned over to the revised United Nations by the United States, without a constitutional amendment, according to an influential federalist lawyer, Philip W. Amram, ${ }^{44}$ although some voices, federalist and others, disagree. ${ }^{45}$

There are actually two somewhat different problems involved, the first being the question of whether a constitutional amendment is necessary before entering negotiations for a world government, a matter that will be discussed below in connection with the Bennett Resolution, ${ }^{46}$ the second being the question whether, after the United States had joined in a federal government, amendments or a new

41 Sen. CoN. Res. 56 by Mr. Tobey et al., 81st Cong., 1st Sess. (1949). SEN. CoN. REs. 81 simply adds to the basic resolution: " . . . wbich will invest it with veto-free authority to make binding decisions in all international disputes and provide it with an adequate police force to compel obedience thereof."

42 H. R. CoN. REs. 64-75, 77-80, 82-94, 104-106, 108, 133, 136, 81st Cong., 1st Sess. (Various sponsors and dates).

43 Wright, Amending or Developing the U.N. Charter, 2 Conason CaUSE 409 (1949).

44 Amram, Why Amend Our Constitution?, 8 Wordd Government News No. 82, p. 13 (1950).

45 Davenport et al., Amending the U.S. Constitution, 2 Comoron CaUSE 401 (1949).

46 Appendix H, infra at note 50. 
United States constitution would be required. Federalists like Amram point out that the Constitution contains no provision applicable to the problem posed; the Framers never dreamed that the people might later consider joining a larger polity. Although they did not go so far as to state that the Constitution created a "perpetual union" in the ambitious terms of the Articles of Confederation, Article $V$ forbids forever any amendment which would deprive a state of its, equal suffrage in the Senate without its consent. How the matter might arise in a practical sense may be seen by considering how the World Federation resolution envisages a world constitution might be presented to the United States for ratification; barring utter chaos in the meantime, any such instrument, whether an agreement under Article 51 of the United Nations Charter, amendments arrived at under Article 108 or a new Charter drafted by a General Conference pursuant to Article 109, would be presented to the President for ratification in either of two ways:

1. As the draft itself might provide, or

2. Pursuant to American constitutional processes, as Americans should determine.

Of course if the draft itself prescribed the method for its own ratification, that method would presumably be followed, but it must be remembered that $143,000,000$ people cannot act spontaneously. The President and Congress and perhaps the Supreme Court would have to decide under established constitutional practices whether the directions for ratification in the draft could be followed, and inevitably the President and Congress would be responsible for directing and financing the ratification. When the Congress of the Confederation provided for the Philadelphia Convention, it directed that the expected revision of the Articles of Confederation should be "agreed to in Congress and confirmed by the States," but the Framers directed ratification by state conventions. Ratification did occur by state conventions, to be sure, ${ }^{47}$ but by the sufferance of the state governments which necessarily had to conduct the elections of the delegates according to prevailing election practices, underwrite the expenses of the conventions, make arrangements for them and then operate the state governments in such a way that the new federal government could operate within its own sphere as contemplated.

On the other hand if the draft, as is commonly the case with international agreements, provided for ratification by the constituent states pursuant to their respective constitutional processes, the Presi-

47 Davenport, supra note 45 , at 403 . 
dent, Congress and perhaps ultimately the Supreme Court would have to determine just what those processes required. However extensive the treaty-power may be, ${ }^{48}$ it has not been seriously suggested that so drastic a constitutional step as joining the Umited States in a world federation should be attempted by the President and two-thirds of the Senate. Another course might be to consider the draft an amendment to the Constitution which would certainly require ratification pursuant to Article $V$, either by state legislatures or state conventions as Congress might direct. How satisfactory this would be depends upon whether the rotten-borough type of representation in our government, based on old regional compromises, neglect of required reapportionment, and racial restrictions at the ballot-box, could be relied upon to express accurately the decision of the American people whether or not to join the world federation.

If ratification pursuant to Article $V$ were not deemed desirable by the President and Congress, the next question they would face would be whether any alternate procedure, be it national or state referenda, national or regional conventions or something else, could be followed without an enabling amendment to the Constitution. Should it be possible to pass such an enabling amendment with reasonable promptness, the present American federal structure might have a better chance to survive more or less intact and be adapted by the use of existing administrative and judicial machinery to its proper role in the world federation.

The argument against the view that an amendment of the Constitution would be necessary in order to join a world federation rests on the precedent of the ratification of the Constitution by conventions and avoids the troublesome practical questions of administering the ratification process by assuming so overwhelming a popular demand for ratification that a dissenting minority would be unable to rely on legal obstacles to delay the process. Since it is probable that joining a world federation will become an immediate political issue only during a period of warfare or the imminent threat of large-scale violence, ratification could probably be managed in some such fashion by a determined President if he so desired.

\section{The Battle Resolution}

A resolution proposed in the House by Mr. Battle, House Concurrent Resolution $15,{ }^{49}$ in forthright fashion urges the President to take

49 Appendix G, infra at 475 . 
the initiative in calling a General Conference of the United Nations pursuant to Article 109 of the Charter in order to make the United Nations "capable of enacting, interpreting, and enforcing world law to prevent war." As against its specific character in naming Article 109 as the vehicle for strengthening the United Nations, the Battle Resolution does not mention world federation as the goal of the General Conference, but in any event the resolution does not raise any issues which have not been discussed already.

\section{The Bennett Resolutions}

The problems of whether a constitutional amendment is required, its form and the vexing problem of annending a world constitution are boldly dealt with in two different resolutions introduced on the same day by $\mathrm{Mr}$. Bennett of Florida. In House Joint Resolution $270^{50}$ an amendment to the United States Constitution is proposed for approval by Congress and ratification by the state legislatures:

\section{ARTICLE}

The United States Government may participate in a world federal government to enact and interpret world law and to enforce such law by a world police force and other appropriate means; Provided, that the powers of such world government be limited to the prevention of war and of international aggression; And provided further, that two-thirds of each House of the Congress of the United States approve the constitution of sucl limited world government.

An amendment to the constitution of such a world government shall not be binding on the United States if it increases the limited powers herein specified or if it has not been approved by two-thirds of each House of the Congress of the United States.

Unique among the pending resolutions in its specification of a proposed amendment, the first of the Bennett Resolutions deserves study. The matter of authority for the United States Government to negotiate for a world governinent would be settled by the amendment; a President sworn to uphold the Constitution need thereafter have no qualms about imitiating action toward a world government which might in many respects supersede the Constitution, and die-hard isolationists would lose one weapon otherwise available for smiping during the international negotiations.

The limitation of the powers of the international government to those for "the prevention of war and of international aggression," if strictly interpreted, does not go beyond the minimal objectives of the

50 Appendix $\mathrm{H}$, infra at 476. 
Culbertson Resolutions and would effectually settle the problems of reconciling the war powers of the Constitution and those to be granted to the international government.

Ratification of the constitution of the world government is provided for in advance by the requirement of a two-thirds vote of each House of Congress, the same percentage specified in Article $\mathrm{V}$ of the Constitution for Congress to propose amendments to the legislatures or for a convention to propose amendments. How accurately this method of ratification would reflect public opinion has already been questioned, but selection of a given method would eliminate delays and uncertaimty over what are essentially matters of procedure.

The second paragraph of the proposed amendment might be an awkward piece of luggage for the United States delegates to take to a world convention, and if it should not be feasible to persuade the international convention of the United States view, the value of the whole amendment would be diluted by the necessity of seeking another without the troublesome second paragraph. If such a provision is politically desirable and practically attainable, its proper place would be, in somewhat different form, in the world constitution as a limitation on the powers granted to the world government.

The second resolution Mr. Bennett submitted, House Concurrent Resolution $76,{ }^{51}$ in contrast to the first, urges strengthening the United Nations but then goes on to propose a constitutional amendment "whereby the United States Government can be given specific authority to participate in a world federal government, limited as hereinafter described, to be created by amendment to the United Nations Charter or by a world constitutional convention." The limitation on the world government referred to would be "preserving peace and preventing aggression through the enactment and interpretation of world law, and enforcement thereof by a world police force and other appropriate means." The second Bennett Resolution is only slightly more specific than the World Federation Resolution and the same constitutional considerations are applicable to it.

\section{World Constitution Resolution}

Within three months after the holocaust at Hiroshima The Conlmittee to Frame a World Constitution was organized at the University of Chicago under the leadership of Chancellor Robert M. Hutchins. Composed of a small working group of distinguished scholars in fields as diverse as law and literature, assisted by a research staff, 
- the Committee worked for two years, accumulated 4,500 pages of studies and then offered to the world "as a proposal to history" their Preliminary Draft of a World Constitution."

Senate Concurrent Resolution 66, ${ }^{53}$ the World Constitution Resolution, begins with a remarkable statement in its preamble, "in order to achieve universal peace and justice," (italics added) the only world government resolution before Congress which clearly transcends the prevention of war for the benefit of the nation which has most to lose in war. The World Constitution Resolution goes on to specify Article 109 of the Charter of the United Nations, providing for a General Conference, to be used as was the amending power in the Articles of Confederation, to adopt a new international charter. Noting that a proposed world constitution has already been prepared (The Preliminary Draft of a World Constitution), "based upon the principles of peace through justice with both social rights and civil rights for all peoples," the Resolution then calls upon the President to request a General Conference of the United Nations to establish "a true world government through adoption of such a constitution." If such a General Conference is not called within one year after adoption of the Resolution, the President is then to call a "world constitutional convention of delegates elected directly by the people for the purpose of adopting a world government constitution."

Space prevents an analysis here of the 33 richly filled pages of the Preliminary Draft of a World Constitution, which may be described briefly as a maximalist document, utilizing constitutional devices from many sources, to establish a federal government on a hierarchy of regional federal governments, and directed toward freedom and justice as the only practical means of achieving peace. For the purpose of this paper it will be sufficient to examine the impact of a document such as the Preliminary Draft on the constitution of the United States.

If the first alternative of the World Government Resolution were to be followed and a world constitution drafted by a General Conference of the United Nations, its ratification by the United States would raise constitutional problems which have already been mentioned in reference to other resolutions. If, however, the second alternative were adopted, a world constitutional convention of delegates

62 (1948). Reviewed by the writer, 35 A. B. A. J. 656 (1949). A brief account of the history of the Committee will be found in 1 Common Cause 11 (1947), a monthly periodical devoted to discussion of the Preliminary Draft and of the problems of world government.

53 Appendix J, infra at 476. 
elected directly by the people, the situation provided for in the Preliminary Draft might arise. In Article 45 of the Draft ${ }^{54}$ such a Founding Convention is authorized, its organization to be determined by the General Assembly of the United Nations. Election of delegates for such a convention would necessarily have to be directed and financed in the United States by existing federal and state governments because of the magnitude and expense of the undertaking, and for a further reason. Article 46 of the Preliminary Draft authorizes the Founding Convention itself to establish the "Federal Republic of the World." If such a provision were to form the basis for the calling of the world convention, it would be desirable that the selection of delegates with such vast power should have the sanction of the existing governments. The alternative would be dangerously close to the Communist techmique of establishing governments through selfchosen soviets, "action committees," and such. Once a world constitution along the lines of the Preliminary Draft were promulgated, the Constitution of the United States would require drastic revision in order to be fitted to the new state of affairs, although many of its noblest provisions would unquestionably survive.

\section{CONCLUSION}

No believer in an international order governed by law rather than violence can be anything but heartened by the intense interest in world government evinced by the resolutions before Congress which have been discussed. ${ }^{55}$ Although it is recognized that political considerations may require generality rather than particularity at this stage in delineating the relationship between world government and the Constitution of the United States, it is also true that some constitutional problems must be faced eventually and a discussion of them by world government proponents now may bear fruit later in more sound and generally acceptable solutions. Whatever the constitutional difficulties, if the people of the United States desire to join in establishing a world government, they will do so. The Constitution of the United States and the wealth of 160 years of constitutional experience it has provided, rather than to be avoided, mistakenly, as a barrier to progress, should be viewed as a bridge to a still "more perfect union."

54 The Conamtree to Fraje a Wordd Constitution, Preliminary Draft of a WORLD Constirutron 35 (1948).

55 Because of the general inaccessibility even in the larger libraries of documents relating to proposed legislation, the pertinent resolutions are here appended. 


\section{AppeñIX A}

SEn. Con. Res. 72 by Mr. Ferguson (for himself, Mr. Graham and Mr. Kefauver), 81st Cong., 2d Sess. (1950).

Whereas the United Nations is the world's best hope for the maintenance of international peace, security and justice; and

Whereas in the three years of its experience the United Nations has both demonstrated strength and revealed weaknesses; and

Whereas, in the light of this experience the United Nations can be made stronger by developnient of its powers, its procedures, its facilities, and policies of its members;

Therefore, be it resolved by the Senate (the House of Representatives concurring):

1. That the Congress reaffirms its faith in the United Nations as the cornerstone of the international policy of the United States, and that the President be advised that it is the sense of the Congress that the United States should cooperate with other governments for the strengthening of the United Nations, by interpretation of the Charter, by action taken or usages developed under the Charter, by supplementary agreements among nations who desire thus to further the purposes of the Charter, or ultimately, if necessary, by amendment of the Charter;

2. That it is the sense of the Congress that the United States should cooperate with other governments in steps for the strengthening of the United Nations, in particular-

(a) "voluntary agreement to remove the veto from all questions involving pacific settlements of international disputes and situations, and from the admission of new niembers."-Senate Resolution 239, June 11, 1948.

(b) effort to achieve immediate membership of all states qualified for membership under article 4 of the Charter to the end of making the United Nations universal;

(c) elimination of the reservations made hy the United States to its acceptance of the optional clause of the Statute of the International Court of Justice; and acceptance by all states of the optional clause without reservations, so as to give the Court compulsory jurisdiction in legal disputes as defined in article 36 of the statute.

(d) further development of the armed guard force and field service under the Secretary-General in order to assure adequate protection and assistance to missions of the United Nations in the normal course of their operations.

(e) for the renewed efforts, at a political level, to secure agreements for contribution of forces and assistance, under the provisions of article 43 of the Charter;

(f) utilization by all members of the United Nations of suitable measures for collective self-defense under article 51 of the Charter as necessary to maintain peace and security;

(g) direct administration by the United Nations of certain disputed areas where such direct administration would contribute to the peace of the world;

(h) passage of appropriate legislation to facilitate the provision of independent sources of revenue for the United Nations in addition to the revenue provided hy contributions nade by members;

(i) support the principles of the United Nations Charter respecting fundamental freedoms;

(j) preparation by the International Law Commission of the United Nations of an international criminal code and of a statute for an international criminal court;

(k) carry out as far as possible, through the United Nations, the program of technical assistance to underdeveloped countries. 


\section{APPENDIX B}

Sen. Con. Res. 52 by Mr. Thomas and Mr. Douglas, 81st Cong., 1st Sess. (1949).

Whereas the United States by repeated declarations and actions has clearly committed itself to the principle that the peace of the world can only be preserved by the use of pooled forces to resist and to deter aggression; and

Whereas in furtherance of this principle the United States has cooperated wholeheartedly in the formulation and activities of the United Nations, in the Pact of Rio de Janeiro which was designed to protect the American hemisphere from attack, and is now negotiating the North Atlantic Security Pact which is similarly designed to protect from assault states bordering and adjacent to the Atlantic; and

Whereas all the members of the United Nations are bound to refrain in their international relations from the threat or use of force against the territorial integrity or political independence of any state, or in any other manner inconsistent with the purposes of the United Nations, and to give the United Nations every assistance in any action it takes in accordance with the present Charter to carry out its purposes; and

Whereas one purpose of the United Nations is to maintam international peace and security and to that end to take effective collective measures for the prevention and removal of threats to the peace, and for the suppression of acts of aggression or other breaches of the peace; and

Whereas the Charter permits member states to supplement the provisions of the Charter by regional or general arrangements for collective self-defense, and such an arrangement can give the General Assembly powers normally exercised by the Security Council; and

Whereas the General Assembly of the United Nations is capable of meeting on short notice and acting prounptly and justly to determine the fact of aggression when the Security Council is prevented from taking action against aggression because of the voting procedures requiring unanimity of the principal powers to authorize military action; and

Whereas the Senate Resolution 239 of June 11, 1948, im addition to favoring the association of the United States with regional arrangements in accordance with the purposes and principles of the Charter, urged the United States to make clear its determination to exercise its right of collective self-defense under Article 51 should any attack occur affecting its national security; to contribute to the progressive development of regional and other collective arrangements; to make maximum efforts to obtain agreements to provide the United Nations with armed forces as provided by the Charter; and to reaffirm the policy of the United States to achieve international peace and security through the United Nations; and

Whereas the national security of the United States may be affected by attacks in areas other than the Atlantic Area:

Therefore be it

Resolved by the Senate (the House of Representatives concurring),

(i) That the Congress reaffirm its faith in the United Nations as the cornerstone of the international policy of the United States and as an institution which can progressively be made more adequate to assure the security of its members;

(ii) That to this end the Congress pledges its support to a supplementary agreement under Article 51 of the Charter open to all members of the United Nations, by which the signatories agree, if the Security Council is prevented from fulfilling its duties, to coine to the aid of the victim of attack if requested to do so hy a two-thirds vote of the General Assembly, including three of the permanent meinhers of the Security Council; (iii) That such an agreement should specify the forces that each signatory agrees to 
maintain, under the spirit of paragraphs 1 and 2 of Article 43, for immediate use of the United Nations-

(a) upon call of the Security Council, or

(b) upon call of the General Assembly by a two-thirds vote, including at least three of the permanent members of the Security Council, and

(iv) That such an agreement should specify that if a inatter pertaining to a threat to or breach of the peace, or act of aggression, is on the agenda of the Security Council, and the Security Council is prevented from fulfiling its duties, the signatories who are members of the Security Council will take such steps as may be required to remove it from the agenda of the Security Council; and

(v) That such an agreement should come into force when ratified by a majority of the United Nations including three of the permanent members of the Security Council.

Sec. 2. Such an agreement shall not in any way impair the inherent right of the parties to engage in self-defense under Article 51 of the United Nations Charter, individually or through other collective arrangements consistent with their obligations under the United Nations Charter, or the North Atlantic Security Pact, or the Pact of Rio de Janeiro.

APPENDIX C

H. R. CoN. Res. 5 by Mr. Holifield, 81st Cong., 1st Sess. (1949).

Resolved by the House of Representatives (the Senate concurring), That it is the sense of the Congress that-

(1) The United Nations Charter shall be revised, so that its existing defects, demonstrated by experience, shall be removed, and the United Nations Organization shall be able to fulfill its stated mission as the principal and most effective instrument for world peace.

(2) The revision of the United Nations Charter shall preserve the full sovereignty of . member states except for acts of aggression and armanient for aggression, to be specifically defined in the Charter.

(3) The revision of the United Nations Charter be undertaken or supported by the United States Governunent without delay and in a manner that shall most effectively parallel and integrate the measures for world economic recovery already undertaken or yet to be undertaken by the Congress of the United States.

(4) This revision shall be so designed that the mutual suspicion and fear now driving the world into opposite military canips shall be replaced by mutual confidence in a United Nations strong enough to guarantee any member nation, however large or small and whatever its form of government, against armed violence by any other nation.

(5) The revision of the United Nations Charter shall be carried out with the approval of all member states if possible; but in the event that any permanent member state should veto the proposals for revision, the United States shall join with other likeminded states in accordance with article 51 of the United Nations Charter or in any other manner acceptable to the majority of member states, in establishing, on the basis of the revised United Nations Charter, a more effective international organization for inutual defense without the participation of the abstaining state or states.

(6) As proof of America's unbending will to peace, membership in the revised international organization shall remain open to any abstaining state or states not engaged at the time in a war of aggression against a member state, and on the same conditions which prevail for member states.

(7) The revision of the United Nations Charter shall contain the following specific provisions which are deemed the minimum necessary to remove the atomic cloud now hanging over the world, reheve the backbreaking load of the armament race now going on, and, by firm action now, avert the third world war later:

(a) Ehmination of the veto right by a permanent member in the Security Council but 
only in matters of aggression, armament for aggression, and admission to membersbip in the United Nations. Aggression shall be prohibited and defined in the Charter, as an attack with weapons of violence by a state (or its citizens) against the recognized territory of a member state; or illegal occupation by a state of territory outside the recognized and established borders of said state and its possessions. Armainent for aggression shall be prohibited and defined in the Charter, as the production of atomic or other weapons of mass destruction, or the production of heavy armainent beyond agreed quotas, or refusal to submit to inspection. To conform to the changes in the veto rigbt, representation in the Security Council shall be revised so as to include: Two members each from the United States, the British Commonwealth, and the Union of Soviet Socialist Republics; one each from France and China; and two selected collectively by the remaining member states. Decisions on vetoless matters shall be made by a majority of six out of ten.

To interpret the revised United Nations Charter, the International Court of Justice shall be similarly reorganized, or a new World Court established, with power to judge in specific matters dealing with aggression of both governments and individuals.

(b) Prevention of armainent for aggression. In the inatter of atomic weapons, this shall be accomplished by adoption of the official United States proposal for an Atomic Development Authority; in the matter of heavy armament (such as warships, warplanes, and heavy guns) by a world-wide quota limitation of its production in the following manner.

The Security Council shall estabhsh yearly the maximunz of heavy armament to be produced in the world. Of this total, each of the five permanent member states shall bave an individual production quota which it may not exceed; and the remaining member states shall have a collective quota, to be produced in their territories by an Armament Authority under the management of the Security Council. Armament production quotas shall be: The United States, tbe British Commonwealth, and the Union of Soviet Socialist Republics-20 per centum each of the fixed world total; France and China10 per centum each; 20 per centum to be the collective quota of the reinaining member states. The Security Council shall have full rights of inspection.

(c) Establishınent of an effective world police force, to consist of one international contingent as the active force and five national contingents operating as reserves when needed.

The international contingent, under direct control of the Security Council, shall consist of volunteers recruited exclusively from the citizens of the smaller member states, and shall be equipped with the small nations' collective quota of heavy armament. It shall be stationed by agreement, in internationalized bases in the smaller states of Europe and Asia, and as policing troops in Germany or other territories when placed under United Nations supervision.

The arined forces of the five major powers shall be the five national contingents. They shall remain under full sovereignty of their respective governments, except that in time of peace their effective strength shall be automatically limited by their agreed quotas of heavy armament production; and except that the governments of the permanent member states shall, subject to their constitutional processes, be pledged to make their national contingents available as reserves to the international contingent upon majority decision of the revised Security Council and World Court in specific inatters of aggression and armament for aggression.

This tyranny-proof and yet overwlielming retaliatory power of the world police force shall also serve as a decisive deterrent against aggressors with bacteriological or chemical weapons or other weapons of mass destruction not easily inspectable.

In the event that a major state shall refuse to participate in the foregoing provisions for the elimmation of the world armament race and the establishment of a world peace force, then the revised Security Council shall proceed at once to the establishment of 
the international contingent; furthermore, it shall establish an emergency quota of heavy-armament production, to be distributed by agreement among the member states in proportion to their resources, so designed as to make certain that any outside state shall be unable to compete with the overwhelming armament production of the rest of the world, nor engage in acts of aggression against member states.

(8) Until such time as the foregoing provisions for the Revised Umited Nations (RUN plan), or similar provisions, shall be put into effect, the armed forces of the United States and its weapons of every kind shall be maintained at wholly adequate levels.

\section{APPENDIX D}

Sen. Res. 133 by Messrs. Sparkman, Aiken, Capehart, Cain, Flanders, Hendrickson, Hill (Ala.), Hoey, Johnson (Colo.), Mundt, Stennis, 81st Cong., 1st Sess. (1949).

Whereas the necessity for firm, prompt, and umited defense by nations of the North Atlantic area justifies the purposes of the North Atlantic Treaty, now before the Senate; and

Whereas the effectiveness of the North Atlantic Treaty will depend largely on the manner and methods used to implement it; and

Whereas the best hope for world peace hes in the capacity of the United Nations to fulfill its primary responsibility for the maintenance of international peace and security, and a declared purpose of the North Atlantic Treaty is to strengthen the United Nations:

\section{Therefore be it}

Resolved, That the President be advised of the sense of the Senate that a fundamental ohjective in the implementation of the North Atlantic Treaty, upon its ratification, should be to seek without delay the revision of the United Nations Charter so that-

A. The paralyzing veto right in defined matters of aggression shall be removed;

B. The rising threat of the atomic catastrophe be averted and the backbreaking load of the armament race be lifted; and

C. An effective but tyranny-proof international police force be established imder a workable Security Council and World Court.

In the event that a permament member vetoes these revisions of the United Nations Cbarter under its Articles 108 or 109, then, under its Article 51, the Atlantic Pact should be supplemented by a World Pact for the establishment, within the Umited Nations, of a larger organization for mutual defense, dedicated to the foregoing objectives and open to all nations; to the end that a united world front of all cooperating nations, in possession of overwhelming atomic and military power, and based on the principle of enforceable law against aggression or armament for aggression, shall avert, by firm action now, the Third World War later; and be it further

Resolved, That among the immediate objectives in the implementation of the North Atlantic Treaty should be:

I. The establishment, in cooperation with other member states, of an emergency defense force, to be called the Atlantic International Contingent, to operate in defense against armed attack as auxiliary to the national armed forces of participating member states.

The International Contingent-a halanced land, sea, and air force-should be recrmited from volunteers who are citizens of smaller sovereign states only, that is, states not possessing their own large military establishments. It should be a highly trained, well-paid professional force, owing its allegiance to the Atlantic Council. It should be stationed in western Germany or, upon mutual agreement, in special bases provided by the smaller member states. Its use and operations should not limit the constitutional safeguards or processes of member states nor commit them to the use of their national armed forces. 
A specified part of the moneys, goods, and lend-lease armament when appropriated by the United States Government in accordance with Article 3 of the North Atlantic Treaty shall be expended to help equip and maintain the International Contingent.

II. The organization and command of the Atlantic International Contingent should be vested in the special Defense Committee provided in Article 9 of the North Atlantic Treaty. The Defense Committee should consist of seven delegates, as follows:

United States, two; British Commonwealth-United Kingdom, one; Canada, one; Latin Europeans-France, one; Italy, one; other smaller member states, one selected to represent thein collectively.

The Defense Committee should act upon an affirmative vote of six out of seven members. The details of representation and voting procedure on the Defense Committee may be arranged differently, provided the paralysis arising from a requirement of unanimous consent of all nember states is avoided.

Excerpt from Statement by Senator John Sparkman on Sen. Res. 133: "The purpose of the resolution is not to thwart or oppose the ratification of the North Atlantic Treaty. We accept the fact that the North Atlantic Treaty will be ratified without reservations, and I personally favor such outright ratification of the pact. The purpose of the resolution is to point the way toward a more effective implementation of the Atlantic Pact than that which has been suggested in the military aid program.

"The resolution seeks to achieve a double goal-the ultimate goal of revision of the Umited Nations and the immediate goal of setting up a nuclear international police force within the Atlantic community."

\section{APPENDIX E}

II. R. CoN. REs. 100 by Mr. White (Idaho), 81st Cong., 1st Sess. (1949).

Resolved by the House of Representatives (the Senate Concurring)

That it is the sense of the Congress that it should be the fundamental objective of the foreign policy of the United States to support and strengthen the United Nations in order to maintain peace and prevent war by joining with governments composing the United Nations in adopting an International Charter. The nations subscribing to the Charter will create no supergovernment and will insure the retention of the sovereignty of every nation.

The nations subscribing to the Charter will establish a World Court composed of proportionate representatives of the signatory nations, and an International Commission implemented with an international army and navy, each signatory nation to have proportionate representation on the Commission, and supply a proportionate quota of the policing force.

The personnel composing the policing force not to be permitted to serve in the country of which they are nationals.

The Commission to maintain freedom of the air and freedom of the seas with universal disarmament;

No nation to be permitted to maintain a navy or armed force above its domestic policing requirements;

All international disputes to be settled by the Commission under the rules of judicial procedure with right of appeal to the World Court, whose detision shall be final and enforced by the International Commission.

The subscribing nations will establish an International Monetary System in which the 
monetary units of the several governments shall be made interchangeable and standard by weight and fineness to the metals gold and silver at a ratio of relative value between the two monetary metals to be fixed by international agreement.

\section{APPENDIX F}

Sen. Con. Res. 57 by Mr. Kefauver et al., 81st Cong., 1st Sess. (1949).

Whereas the parties to the North Atlantic Treaty have declared themselves "determined to safeguard the freedom, common heritage, and civilization of their peoples, founded on the principles of democracy, individual biberty, and the rule of law," and "resolved to unite their efforts for collective defense and for the preservation of peace and security"; and

Whereas they have agreed in article 2 of that treaty to "contribute toward the further development of peaceful and friendly international relations by strengthening their free institutions, by bringing about a better understanding of the principles upon which these institutions are founded, and by promoting conditions of stability and well-being" and to "seek to eliminate conflict in their international economic policies" and to "encourage economic collaboration between any or all of them"; and

Whereas the principles on which our American freedom is founded are those of the federal union, which were applied for the first time in history in the United States Constitution; and

Whereas our Federal Convention of 1787 worked out these principles of union as a means of safeguarding the individual liberty and common heritage of the people of thirteen sovereign States, strengthening their free institutions, uniting their defensive efforts, encouraging their economic collaboration, and severally attaining the aims that the democracies of the North Atlantic have set for themselves in the aforesaid treaty; and

Whereas these federal union principles have succeeded impressively in advancing such aims in the United States, Canada, Switzerland, and wherever other free peoples have applied them; and

Whereas the United States, together with the other signatories to the treaty, has promised to bring about a better understanding of these federal principles and has, as their most extensive practitioner and greatest beneficiary, a unique moral obligation to make this contribution to peace; and

Whereas the United States and the other six democracies which sponsored the treaty have, by their success in drafting it and extending it to others, established a precedent for united action toward the attainment of these aims, and the creation of a free and lasting union:

Now, therefore, be it

\section{Resolved by the Senate (the House of Representatives concurring),}

That the President is requested to invite the democracies which sponsored the North Atlantic Treaty to name delegates, representing their principal political parties, to meet this year with delegates of the United States in a federal convention to explore how far their peoples, and the peoples of such other denocracies as the convention may invite to send delegates, can apply annong them, within the framework of the United Nations, the principles of free federal union.

\section{APPENDIX G}

H. R. CoN. Res. 15 by Mr. Battle, 81st Cong., 1st Sess. (1949).

Whereas all the world deeply desires durable peace; and

Whereas the United Nations was created as an instrument to preserve the peace of the world; and

Whereas experience increasingly indicates that the United Nations in its present structure is not fully adequate for this task; and 
Whereas the United Nations Cbarter in its article 109 provides a procedure whereby the Charter of the United Nations may be revised and amended:

Now, therefore, be it

Resolved by the House of Representatives (the Senate concurring),

That it is the sense of the Congress that the President of the United States should immediately take the initiative in calling a General Conference of the United Nations pursuant to article 109 for the purpose of nuaking the United Nations capable of enacting, interpreting, and enforcing world law to prevent war.

\section{APPENDIX H}

H. R. JT. Res. 270 by Mr. Bennett (Fla.), 81st Cong., 1st Sess. (1949).

Resolved by the Senate and House of Representatives of the United States of America in Congress assembled (two-thirds of each House concurring therein), That the following article is proposed as an amendment to the Constitution of the United States, which shall be valid to all intents and purposes as a part of the constitution when ratified by the legislatures of three-fourths of the several States:

Article.

The United States Government may participate in a world federal government to enact and interpret world law and to enforce such law by a world police force and other appropriate means: Provided, That the powers of such world government be limited to the prevention of war and of international aggression: And provided further, That two-thirds of each House of the Congress of the United States approve the constitution of such limited world government.

An amendment to the constitution of such a world government shall not be binding on the United States if it increases the limited powers herein specified or if it has not been approved by two-thirds of each House of the Congress of the Urited States.

APPENDIX I

H. R. CoN. REs. 76 by Mr. Bennett (Fla.), 81st Cong., 1st Sess. (1949).

Resolved by the House of Representatives (the Senate concurring),

(1) That it is the sense of the Congress that it should be a fundamental objective of the foreign policy of the United States to support and strengthen the United Natiods;

(2) that by constitutional convention or by action of the Congress an amendment to the Constitution of the United States should be drafted, debated, and considered for adoption, whereby the United States Government can be given specific authority to participate in a world federal government, limited as hereinafter described, to be created by amendment to the United Nations' Charter or by a world constitutional convention; and (3) that the powers of such world governnent should be limited to preserving peace and preventing aggression through the enactment and interpretation of world law, and enforcement by a world police force and other appropriate means.

ApPENDIX J

SEN. CoN. RES. 66 by Mr. Taylor (Idaho), 81st Cong., 1st Sess. (1949).

Whereas, in order to achieve universal peace and justice, the present Charter of the United Nations should be changed to provide a true world government constitution; and

Whereas article 109 of the present Charter of the United Nations provides for a general conference to make alterations in said Charter; and

Whereas similar amendatory powers in tbe Articles of Confederation were used by the people of the United States in 1787 to adopt a new Constitution to insure a unified, peaceful nation; and 
Whereas the combined effort of many able and intelligent citizens has resulted in the preparation of a proposed world constitution based upon the principles of peace through justice with both social rights and civil rights for all peoples:

Now, therefore, be it

Resolved by the Senate (the House of Representatives concurring),

That it is the sense of Congress that the President of the United States should immediately take the initiative in requesting a general conference of the United Nations pursuant to article 109 for the purpose of establishing a true world government through adoption of such a constitution; and if such a general conference is not called within one year after the adoption of this resolution, the President of the United States should then call a world constitutional convention of delegates elected directly by the people for the purpose of adopting a world government constitution. 